\title{
ZNACZENIE BANCASSURANCE W PROCESIE ZARZĄDZANIA SPRZEDAŻĄ PRODUKTÓW UBEZPIECZENIOWYCH (ANALIZA DANYCH STATYSTYCZNYCH ZA LATA 2012-2018)
}

\section{Kinga Stęplewska*}

\section{THE IMPORTANCE OF BANCASSURANCE IN SALES MANAGEMENT PROCESS OF INSURANCE PRODUCTS (ANALYSIS OF STATISTICAL DATA SINCE 2012-2018)}

\begin{abstract}
The aim of the article is to present and evaluate the situation of bancassurance in Poland and establishing the importance of this channel in the sale of insurance products. The paper concerns on product distribution, which is a very important part of the activity of any enterprise. One of the insurance product distribution channels is bancassurance based on cooperation between banks and insurers.

Methodology. To achieve the goal quantitative changes were analysed, as well as a review of the introduced legal solutions in relation to bancassurance. Data on the bancassurance market in Poland are presented in the article, including the number and sales structure in this channel since 2012 to 2018.

Results of the research. The analysis made it possible to conclude that bancassurance is an important distribution channel for insurance products with high development potential. However, in the analysed period, sales through this channel showed a downward trend, which was mainly caused by the introduction of new recommendations and legal regulations concerning the distribution of insurance products.
\end{abstract}

Keywords: insurance companies, insurance products, distribution channels, bancassurance, banks.

JEL Class: G22, G21.

\footnotetext{
* Dr, Wydział Prawa i Nauk Społecznych, Uniwersytet Jana Kochanowskiego w Kielcach; https://orcid.org/0000-0003-29196812.
} 


\section{WPROWADZENIE}

Z punktu widzenia towarzystwa ubezpieczeniowego, które tak jak inne przedsiębiorstwa dąży do rozwoju, najważniejszą kwestią jest pozyskiwanie i utrzymywanie klientów. Niezależnie od przyjętej formy działalności danego zakładu ubezpieczeń (spółka akcyjna lub towarzystwo ubezpieczeń wzajemnych), kluczowe dla jego dalszego funkcjonowania są przychody ze sprzedaży. Różnice pojawiające się w polityce sprzedażowej zakładów ubezpieczeń wynikają m.in. z rodzaju oferowanych produktów ubezpieczeniowych. W przypadku ubezpieczeń krótkoterminowych (tj. ubezpieczenia majątkowe) priorytetowe jest pozyskiwanie nowych klientów, natomiast w przypadku produktów długoterminowych (tj. ubezpieczenia życiowe) duże znaczenie ma również utrzymanie obecnych klientów. Ubezpieczenia długo- i krótkoterminowe zostały odpowiednio przyporządkowane do działu I i II ubezpieczeń (art. 9 i załącznik do Ustawy z dnia 11 września 2015 r. o działalności ubezpieczeniowej i reasekuracyjnej) ${ }^{1}$. Sprzedaż produktów może odbywać się z wykorzystaniem własnej sieci ubezpieczycieli lub poprzez pośredników. Jedną z możliwości w ramach sprzedaży pośredniej jest sprzedaż produktów ubezpieczeniowych w ramach współpracy z bankami, korzystając $\mathrm{z}$ ich sieci dystrybucji. Współpraca ta nazywana jest bancassurance.

Celem artykułu jest prezentacja i ocena sytuacji w zakresie bancassurance w Polsce oraz ustalenie znaczenia tego kanału w sprzedaży produktów ubezpieczeniowych. Dla realizacji celu dokonano analizy zmian ilościowych, a także przeglądu wprowadzonych rozwiązań prawnych w odniesieniu do bancassurance. W artykule skoncentrowano się na dwóch głównych pytaniach badawczych: Jaki był udział sprzedaży produktów ubezpieczeniowych przez kanały bankowe w sprzedaży ogółem w analizowanym okresie? oraz Jak kształtowała się sprzedaż polis przez kanały bankowe w poszczególnych działach ubezpieczeń?

Analiza została przygotowana w oparciu o akty prawne i inne dokumenty dotyczące bancassurance ( $\mathrm{tj}$. rekomendacje) oraz dane liczbowe publikowane przez Komisję Nadzoru Finansowego (KNF) i Polską Izbę Ubezpieczeń (PIU). Jako okres badawczy przyjęto lata 2012-2018.

\section{ZARZĄDZANIE SPRZEDAŻĄ PRODUKTÓW UBEZPIECZENIOWYCH - WYBÓR WŁAŚCIWEGO KANAŁU DYSTRYBUCJI}

W przypadku sprzedaży produktów ubezpieczeniowych wybór odpowiedniego sposobu dotarcia do klienta jest bardzo ważny i musi być dopasowany do konkretnego rodzaju ubezpieczenia. Oznacza to konieczność zdefiniowania grupy docelowej, dla której przeznaczony jest dany produkt.

\footnotetext{
${ }^{1}$ Dział I - ubezpieczenia na życie, Dział II - pozostałe ubezpieczenia osobowe i majątkowe.
} 
Kwestie związane z zarządzaniem produktami przez ubezpieczycieli zostały poruszone w Rekomendacjach wydanych dla zakładów ubezpieczeń przez KNF w 2016 r. dotyczących: systemu zarządzania produktem oraz badania adekwatności produktu. Zgodnie z pierwszą rekomendacją efektywny system zarządzania produktem ubezpieczeniowym to taki, który obejmuje pełny cykl życia produktu tj. od momentu zaprojektowania do wycofania produktu z rynku wraz z wywiązaniem się przez zakład ubezpieczeń ze zobowiązań wynikających z umów. Efektywny system zarządzania produktem stanowi integralną i spójną część zarządzania ryzykiem oraz kontroli wewnętrznej, które to elementy łącznie wpływają na wyniki finansowe i wypłacalność zakładu, a także na jakość relacji zakładu z klientami. W związku z powyższym system zarządzania produktem bezpośrednio wpływa na zaufanie klientów do samego zakładu ubezpieczeń, a poprzez to również do całego rynku finansowego (KNF, 2016b: 2).

Zgodnie z powyższą rekomendacją zakład ubezpieczeń powinien tworzyć i wprowadzać na rynek tylko takie produkty (biorąc pod uwagę cechy, ryzyka, opłaty, kanały dystrybucji), które spełnią oczekiwania i interesy docelowej grupy klientów. Oznacza to w pierwszej kolejności rozpoznanie rzeczywistych potrzeb klienta, a następnie zaproponowanie mu produktu, który będzie zaspokajał te potrzeby. Wymaga to przeprowadzenia przez zakład ubezpieczeń szczegółowej analizy produktów zanim zostaną one wprowadzone do obrotu (KNF, 2016b: 7), a w przypadku umów ubezpieczeń na życie, jeżeli są związane z ubezpieczeniowym funduszem kapitałowym (i innych z działu I, gdy wysokość świadczenia uzależniona jest od wahań rynkowych) przeprowadzenia badania adekwatności produktu tzn. przeanalizowanie potrzeb, wiedzy, doświadczenia, sytuacji finansowej klienta, aby zaproponować umowę adekwatną do jego potrzeb (KNF, 2016a: 2-4) $)^{2}$. Ponadto zakład ubezpieczeń powinien przynajmniej raz na rok dokonać przeglądu systemu zarządzania produktem pod kątem jego aktualności i sprawdzenia, czy jest adekwatny do prowadzonej działalności oraz wprowadzić zmiany, jeżeli zachodzi taka potrzeba. Po wprowadzeniu produktu na rynek zakład ubezpieczeń powinien prowadzić stały monitoring oferowanych produktów (KNF, 2016b: 6, 8).

Do omawianej kwestii odnosi się także ustawa z dnia 15 grudnia $2017 \mathrm{r}$. o dystrybucji ubezpieczeń (u.d.u.), która w art. 8 stanowi, że proponowana umowa ubezpieczenia powinna być zgodna $\mathrm{z}$ wymaganiami i potrzebami klienta w zakresie ochrony ubezpieczeniowej.

Powyższe regulacje dotyczą produktów ubezpieczeniowych, niezależnie od tego jaki został przyjęty dla nich sposób dystrybucji. Rekomendacją, która została przygotowana przez KNF specjalnie dla produktów sprzedawanych w ramach kanału bancassurance jest Rekomendacja U. Wyraźnie wskazuje ona na

${ }^{2}$ Obowiązek taki wynika z art. 21 Ustawy z dnia 11 września 2015 r. o działalności ubezpieczeniowej i reasekuracyjnej. 
konieczność dopasowania produktów sprzedawanych przez banki w ramach bancassurance do potrzeb klienta (KNF, 2014: 8).

Działania przedsiębiorstwa, jakim jest zakład ubezpieczeń, powinny zatem opierać się na podejściu rynkowym w procesie zarządzania sprzedażą produktów. Oznacza to, że oferta produktowa przygotowywana przez zakłady ubezpieczeń powinna wynikać z potrzeb i oczekiwań klientów. W procesie tym równie ważny jest wybór odpowiedniego sposobu dotarcia do klienta (por. Czubała, 1997: 222; Filkiewicz, 2009: 120). Elementy te składają się na dystrybucję, która jest definiowana, jako działalność, obejmująca przygotowanie, realizację i kontrolę przepływu produktów z miejsca ich powstania do miejsca zbycia, tj. od producenta do klienta. Przy czym dystrybucja to nie tylko droga i sposób przekazania produktu, ale także działania obejmujące sposoby i miejsce kontaktu $\mathrm{z}$ klientem. $Z$ punktu widzenia zarządzania działalnością towarzystwa ubezpieczeniowego dystrybucja należy do najbardziej istotnych obszarów funkcjonowania przedsiębiorstwa, a decyzje podejmowane w tym zakresie mają bezpośredni wpływ na jego rozwój (Witkowska, 2016: 127; Dołhasz i in., 2009: 212).

Wybór właściwego sposobu dystrybucji powinien być poprzedzony analizą wielu czynników związanych z rynkiem (jego wielkość, potrzeby klientów, konkurencja), produktem (jego rodzajem), dostępnymi kanałami dystrybucji (rodzaje, koszty utrzymania), możliwościami (dostępne zasoby) i polityką towarzystwa ubezpieczeniowego (por. Witkowska, 2008: 29-30; szerzej w: Rodek i Visan, 1997: 230-233).

Kanały dystrybucji są głównym składnikiem dystrybucji, zapewniającym prawidłowy przepływ produktów od producenta do konsumenta tj. przekazanie produktu od towarzystwa ubezpieczeniowego do nabywcy. W ujęciu podmiotowym oznaczają one zbiór organizacji, które współuczestniczą w procesie dostarczania i sprzedaży produktów i usług. W ramach kanału dystrybucji wyróżnia się kanał sprzedaży usług ubezpieczeniowych, którego zakres działań jest węższy niż w przypadku dystrybucji (obejmuje m.in. doradztwo ubezpieczeniowe, zwieranie umowy, płatności, dokumenty ubezpieczeniowe). Należy zaznaczyć, że cały system dystrybucji obejmuje nie tylko podmioty wchodzące w jego skład, ale również rodzaj powiązań między nimi (Lisowski i Zieniewicz, 2015: 336; szerzej w: Witkowska, 2008: 33-34).

Towarzystwa ubezpieczeniowe przyjmują różne sposoby działania w zakresie dystrybucji ubezpieczeń. Niektóre w większym stopniu opierają działalność na własnych kanałach inne korzystają z pośredników. Pierwsza forma daje towarzystwu większą kontrolę i skraca proces sprzedaży. W przypadku korzystania z pośredników, im jest ich więcej, tym kontrola się zmniejsza, a czas sprzedaży wydłuża (Rodek i Visan, 1997: 225).

Zwykle towarzystwa ubezpieczeniowe korzystają z wielu różnych kanałów dystrybucji, dzięki czemu są w stanie dotrzeć do jak najszerszej liczby klientów. 
Właściwa dystrybucja pozwala osiągnąć określony w procesie zarządzania na szczeblu centralnym wizerunek i wiarygodność zakładu ubezpieczeń, a także pozwala budować przewagę konkurencyjną (szerzej w: Witkowska, 2008: 31; Stęplewska, 2015: 84). Nie ma jednego kanału dystrybucji, który można byłoby uznać za najlepszy, czy uniwersalny. Powinien być on tak dobrany, aby był efektywny, biorąc pod uwagę wcześniej wskazane czynniki.

Zgodnie z Rekomendacją dla zakładów ubezpieczeń dotyczącą systemu zarządzania produktem zakład ubezpieczeń powinien podejmować działania, które zapewnią właściwe funkcjonowanie kanałów dystrybucji i będą gwarantowały efektywność systemu zarządzania produktem (KNF, 2016b: 8).

Kwestie dystrybucji ubezpieczeń w Polsce reguluje ustawa $\mathrm{z}$ dnia 15 grudnia 2017 r. o dystrybucji ubezpieczeń, która weszła w życie 1.10.2018 r. W ustawie tej zaimplementowano do polskiego porządku prawnego dyrektywę Parlamentu Europejskiego i Rady (UE) 2016/97 z dnia 20 stycznia 2016 r. w sprawie dystrybucji ubezpieczeń oraz uchylono ustawę z dnia 22 maja 2003 r. o pośrednictwie ubezpieczeniowym.

Dystrybucja ubezpieczeń, zgodnie z powyższą ustawą (art. 4) oznacza działalność wykonywaną wyłącznie przez dystrybutora ubezpieczeń, którym jest zakład ubezpieczeń, agent ubezpieczeniowy, agent oferujący ubezpieczenia uzupełniające lub broker ubezpieczeniowy (art. 3 ust. 1 pkt. 8). Zatem dystrybucja może się odbywać w sposób bezpośredni tj. poprzez uprawnionego przez zakład ubezpieczeń pracownika lub pośredni - w pozostałych przypadkach tj. poprzez pośredników ubezpieczeniowych (art. 4, 3 ust. 1 pkt. 15). Dystrybucja ubezpieczeń polega na (art. 4 u.d.u.): doradzaniu, proponowaniu, wykonywaniu czynności przygotowawczych, zawieraniu, pomocy w administrowaniu, wykonywaniu umów ubezpieczenia lub gwarancji ubezpieczeniowych, a także udzielaniu informacji i opracowywaniu rankingów produktów ubezpieczeniowych (gdy klient może zawrzeć umowę a pomocą stron internetowych lub innych mediów) oraz organizowaniu i nadzorowaniu czynności agencyjnych i brokerskich.

Agenci ubezpieczeniowi i agenci oferujący ubezpieczenia uzupełniające podlegają rejestracji w rejestrze agentów, natomiast rejestracja brokerów następuje w rejestrze brokerów. Rejestr pośredników ubezpieczeniowych prowadzony jest przez organ nadzoru. Oba rejestry są jawne i udostępniane przez organ nadzoru (art. 3 ust. 1 pkt. 2 i art. 52 u.d.u.).

Ze względu na tematykę artykułu, dalsza jego część została zawężona do kwestii dotyczących agentów ubezpieczeniowych, w tym banków zaliczanych do tej grupy.

Agent ubezpieczeniowy to przedsiębiorca (inny niż agent oferujący ubezpieczenia uzupełniające) - wykonujący działalność agencyjną na podstawie umowy agencyjnej. Agent wykonuje czynności w zakresie dystrybucji ubezpieczeń w imieniu lub na rzecz zakładu ubezpieczeń, zwane czynnościami agencyjnymi 
(art. 4 u.d.u.). Czynności agencyjne mogą być wykonywane przez osobę fizyczną, spełniającą warunki zawarte $\mathrm{w}$ art. 19 ust. 1 u.d.u. lub przez osoby prawne, a także spółki nieposiadające osobowości prawnej. Warunki wymienione w art. 19 ust. 1 u.d.u. powinni spełniać w przypadku agentów ubezpieczeniowych oraz agentów oferujących ubezpieczenia uzupełniające, będących spółkami nieposiadającymi osobowości prawnej: wspólnicy tych spółek, o ile są osobami fizycznymi, a w przypadku, gdy wspólnikami tych spółek są osoby prawne - co najmniej połowa ich członków zarządu. Natomiast w przypadku agentów będących osobami prawnymi - co najmniej połowa ich członków zarządu (art. 19 ust. 3 u.d.u.).

Zgodnie z u.d.u (art. 11) pośrednicy ubezpieczeniowi zostali włączeni w proces tworzenia produktu ubezpieczeniowego. Zakład ubezpieczeń, broker oraz agent ubezpieczeniowy, którzy tworzą produkt ubezpieczeniowy zostali zobowiązani do stosowania odpowiedniego procesu zatwierdzania produktu, a także istotnych zmian w produkcie przed wprowadzeniem go na rynek oraz dokonywania przeglądu tego procesu [szerzej w: Malinowska, 2017: 8).

Rozporządzenie delegowane Komisji (UE) z dnia 21.09.2017 r. uzupełniające dyrektywę Parlamentu Europejskiego i Rady (UE) 2016/97 w odniesieniu do wymogów w zakresie nadzoru nad produktem i zarządzania nim dla zakładów ubezpieczeń i dystrybutorów ubezpieczeń (art. 3) podaje, że pośredników ubezpieczeniowych uznaje się za twórców, gdy z całościowej analizy ich działalności wynika, że pełnią oni rolę decyzyjną w tworzeniu i opracowywaniu produktu ubezpieczeniowego (przeznaczonego na dany rynek). Współpraca, a także role pełnione przez zakład ubezpieczeń i pośrednika, jeżeli pełnią rolę decyzyjną przy opracowywaniu i tworzeniu produktu powinny być zawarte w pisemnej umowie, aby umożliwić sprawowanie nadzoru (pkt. 4 preambuły do w/w rozporządzenia).

\section{POJĘCIE I REKOMENDACJE DOTYCZĄCE BANCASSURANCE}

Poprzez pojęcie bancassurance - w ogólnym ujęciu - określa się formę współpracy pomiędzy bankiem a ubezpieczycielem, mającą na celu sprzedaż produktów ubezpieczeniowych $\mathrm{z}$ wykorzystaniem bankowych kanałów dystrybucji. Termin ten został po raz pierwszy wprowadzony we Francji, która została uznana za miejsce powstania tej formy współpracy. Szybki rozwój bancassurance w Europie rozpoczął się w latach 80. XX wieku (Borowiec, 2011: 921; Dominiak, 2018: 273).

Pomimo od dawna funkcjonującego pojęcia bancassurance - nie posiada ono definicji normatywnej. Istniejące definicje powstały na bazie praktyki gospodarczej i są zawarte w różnych dokumentach wydawanych przez m.in. KNF, Związek Banków Polskich (ZBP).

Ze względu na brak ustawowego ujęcia bancassurance sprzedaż produktów ubezpieczeniowych przez banki rozwijała się przez wiele lat w sposób 
niekontrolowany, co stawiało w niekorzystnej sytuacji, klientów korzystających z tego typu usług. W celu poprawy sytuacji na rynku bancassurance, począwszy od 2009 roku tworzone były przez ZBP i organ nadzoru rekomendacje dotyczącego tego obszaru (Orłowski, 2015).

Dwie pierwsze Rekomendacje dotyczyły dobrych praktyk na polskim rynku bancassurance $\mathrm{w}$ zakresie ubezpieczeń powiązanych z produktami bankowymi. Pierwsza została opracowana przez grupę roboczą przy ZBP (ZBP, 2009), a druga dodatkowo przy współpracy z PIU (ZBP, PIU, 2010). Obie zostały przyjęte przez Zarząd ZBP.

W lipcu 2012 r. została przygotowana III Rekomendacja dobrych praktyk na polskim rynku bancassurance w zakresie ubezpieczeń z elementem inwestycyjnym lub oszczędnościowym, opracowana przy współpracy z PIU i zatwierdzona przez Zarząd ZBP, która weszła w życie 1.01.2013 r. Rekomendacja w szczególny sposób skupiła się na określeniu obowiązków informacyjnych banku względem klienta. W dokumencie wskazano minimalny zakres informacji, jakie powinny być przekazane klientowi przed objęciem go ochroną ubezpieczeniową, w szczególności w zakresie: kosztów ponoszonych przez klienta i sposobu ich naliczania, zasad ustalania świadczeń przysługujących klientowi, możliwego ryzyka związanego $\mathrm{z}$ daną inwestycją i konsekwencji wynikających $\mathrm{z}$ rezygnacji $\mathrm{z}$ ochrony ubezpieczeniowej. Bank został zobligowany, aby zapewnić klientowi dostęp do warunków ubezpieczenia i materiałów informacyjnych, zanim klient podejmie decyzję o skorzystaniu $\mathrm{z}$ danej oferty. Zgodnie $\mathrm{z}$ rekomendacją dokumenty przekazywane klientowi powinny być napisane w sposób: przejrzysty, jasny i niebudzący wątpliwości, a sformułowania niejednoznaczne należy interpretować na korzyść klienta. Ponadto banki powinny dołożyć wszelkiej staranności, aby proponując klientowi produkt uwzględnić jego potrzeby, wiedzę i doświadczenia, a także sprawdzić, czy klient spełnia wymogi związane $\mathrm{z}$ objęciem go ochroną ubezpieczeniową (ZBP, PIU, 2012).

Jedną z najważniejszych rekomendacji była Rekomendacja U wydana przez KNF w $2014 \mathrm{r}^{3}{ }^{3}$ Rekomendacja ta dotyczyła dobrych praktyk w zakresie bancassurance i miała na celu poprawę jakości standardów współpracy między zakładami ubezpieczeń a bankami w odniesieniu do produktów ubezpieczeniowych oferowanych przez banki, a także określenie warunków stabilnego rozwoju rynku bancassurance (KNF, 2014: 2). Rekomendacja była skierowana do wszystkich banków, które działały na podstawie przepisów prawa polskiego i współpracowały z zakładami ubezpieczeń w zakresie oferowania ubezpieczeń jako pośrednicy ubezpieczeniowi, oferowały zawarcie umowy ubezpieczenia na cudzy rachunek lub gdy klient był zobowiązany do opłacania składki

\footnotetext{
${ }^{3}$ Rekomendacja została wydana na podstawie art. 137 pkt. 5 Ustawy z dnia 29 sierpnia $1997 \mathrm{r}$.
} 
ubezpieczeniowej w zakresie ryzyka ponoszonego przez bank (KNF, 2014: 4, szerzej w: Maśniak, 2015: 286).

Zgodnie z powyższą Rekomendacją bancassurance oznacza oferowanie ubezpieczeń przez banki na podstawie umów, które są zawierane pomiędzy bankiem a zakładem ubezpieczeń. Bancassurance polega na pośredniczeniu banku w zawieraniu umów ubezpieczenia bądź oferowaniu przez bank możliwości przystąpienia do umowy ubezpieczenia na cudzy rachunek zawartej przez bank (w której bank występuje w roli ubezpieczającego, a klient - ubezpieczonego zgodnie z art. $808 \mathrm{KC}$ ) bądź zawieraniu umów w przypadku, których klient (na podstawie odrębnej umowy) jest zobowiązany pokryć koszty ochrony ubezpieczeniowej banku, w zakresie określonego ryzyka. Rekomendacja przewidywała możliwość oferowania ubezpieczeń powiązanych lub niepowiązanych bezpośrednio z produktem bankowym (KNF, 2014: 6).

Rekomendacja w znacznej części odnosiła się do relacji banku z klientami, mając na celu zabezpieczenie interesów klienta. Bank m.in. powinien zapewnić rzetelną politykę informacyjną tak, aby nie dochodziło do oferowania produktów niedopasowanych do potrzeb klientów. Ponadto bank winien umożliwić klientowi, który jest ubezpieczonym lub jego spadkobiercom, dochodzenie roszczeń, $\mathrm{w}$ przypadku, gdy bank jako podmiot uprawniony zrezygnuje $\mathrm{z}$ dochodzenia o wypłatę świadczenia. Natomiast w sytuacji, gdy bank jest ubezpieczającym podejmuje on działania, które będą w interesie klienta lub jego spadkobierców. Ponadto bank powinien dać klientowi możliwość wyboru produktu ubezpieczeniowego oraz zakładu ubezpieczeń. Rekomendacja obligowała również bank do przekazania klientowi informacji, czy działa on jako pośrednik, czy ubezpieczający (KNF, 2014: 7-8). Podmiotem odpowiedzialnym za opracowanie, zatwierdzenie a także wprowadzanie w życie polityki dotyczącej bancassurance został zarząd banku (KNF, 2014: 11). Banki, które występują w roli agenta ubezpieczeniowego informują na swoich stronach internetowych o wpisaniu do rejestru agentów ubezpieczeniowych, podając m.in. numer wpisu i ubezpieczycieli, na rzecz których wykonują działalność agencyjną, jak również stosowne pełnomocnictwa (przykładowo: www 3-6).

\section{ANALIZA ZMIAN ILOŚCIOWYCH SPRZEDAŻY PRODUKTÓW UBEZPIECZENIOWYCH W RAMACH BANCASSURANCE (W LATACH 2012-2018)}

Głównym miernikiem pozwalającym ocenić poszczególne kanały dystrybucji jest poziom składki przypisanej brutto. Jak pokazują dane zamieszczone w tabeli 1 , dominującym kanałem dystrybucji w Polsce jest sprzedaż produktów ubezpieczeniowych poprzez agentów ubezpieczeniowych. 
Tabela 1. Struktura składki przypisanej brutto wg kanałów dystrybucji w latach 2012-2018 (w \%)

\begin{tabular}{|c|c|c|c|c|c|c|}
\hline \multicolumn{2}{|c|}{ Wyszczególnienie } & $\begin{array}{c}\text { Sprzedaż } \\
\text { bezpośrednia }\end{array}$ & $\begin{array}{c}\text { Agenci } \\
\text { ubezpieczeniowi }\end{array}$ & $\begin{array}{c}\text { Brokerzy } \\
\text { ubezpieczeniowi } \\
\text { i reasekuracyjni }\end{array}$ & $\begin{array}{c}\text { Inne } \\
\text { kanały }\end{array}$ & $\begin{array}{c}\text { Składka przy- } \\
\text { pisana brutto } \\
\text { ogółem } \\
\text { (w tys. zł) }\end{array}$ \\
\hline \multirow{2}{*}{2012} & Dział I & $28,83 \%$ & $63,00 \%$ & $1,61 \%$ & $6,56 \%$ & 36376933 \\
\cline { 2 - 7 } & Dział II & $15,28 \%$ & $63,30 \%$ & $19,31 \%$ & $2,11 \%$ & 25885835 \\
\hline \multirow{2}{*}{2013} & Dział I & $40,24 \%$ & $56,83 \%$ & $1,84 \%$ & $1,08 \%$ & 31264070 \\
\cline { 2 - 7 } & Dział II & $15,92 \%$ & $62,63 \%$ & $19,92 \%$ & $1,54 \%$ & 26276206 \\
\hline \multirow{2}{*}{2014} & Dział I & $33,03 \%$ & $64,53 \%$ & $2,41 \%$ & $0,03 \%$ & 28666872 \\
\cline { 2 - 7 } & Dział II & $15,19 \%$ & $62,49 \%$ & $19,93 \%$ & $2,39 \%$ & 26090211 \\
\hline \multirow{2}{*}{2015} & Dział I & $29,25 \%$ & $65,79 \%$ & $2,51 \%$ & $2,44 \%$ & 27525020 \\
\cline { 2 - 7 } & Dział II & $10,47 \%$ & $64,97 \%$ & $18,57 \%$ & $5,98 \%$ & 26862748 \\
\hline \multirow{2}{*}{2016} & Dział I & $32,52 \%$ & $64,32 \%$ & $3,05 \%$ & $0,11 \%$ & 23846265 \\
\cline { 2 - 7 } & Dział II & $10,41 \%$ & $64,89 \%$ & $17,60 \%$ & $7,10 \%$ & 31777308 \\
\hline \multirow{2}{*}{2017} & Dział I & $31,00 \%$ & $65,88 \%$ & $3,10 \%$ & $0,02 \%$ & 24561267 \\
\cline { 2 - 7 } & Dział II & $13,46 \%$ & $69,44 \%$ & $16,16 \%$ & $0,94 \%$ & 37535390 \\
\hline \multirow{2}{*}{2018} & Dział I & $35,43 \%$ & $60,67 \%$ & $3,85 \%$ & $0,06 \%$ & 21702493 \\
\cline { 2 - 7 } & Dział II & $13,87 \%$ & $67,94 \%$ & $16,87 \%$ & $1,33 \%$ & 40210470 \\
\hline
\end{tabular}

Źródło: opracowanie własne na podstawie bazy danych: KNF, 2012-2018: tablice V.5, V.6, V.12.

Składka przypisana brutto uzyskana przez sprzedaż za pośrednictwem agentów ubezpieczeniowych stanowiła w całym analizowanym okresie ok. 2/3 składki przypisanej brutto ogółem. Była to dominująca forma sprzedaży zarówno w dziale I jak i w dziale II. Analizując pozostałe kanały dystrybucji należy zauważyć, że w dziale I znaczna część sprzedaży odbywa się poprzez kanały bezpośrednie (ok. $30 \%$ ), a w dziale II duży udział w sprzedaży produktów mają brokerzy (ok. 18\%).

Składka przypisana brutto dla poszczególnych działów charakteryzowała się odmiennymi trendami, w dziale I - widoczny jest trend malejący, a w dziale II rosnący. Spadek wartości składki w dziale I wyniósł 14,6 mld zł, czyli jej wartość zmniejszyła się o 40\% w 2018 r. względem 2012 r. Porównując te same lata dla działu II - nastąpił wzrost o 14,3 mld zł tj. o 55\%. 


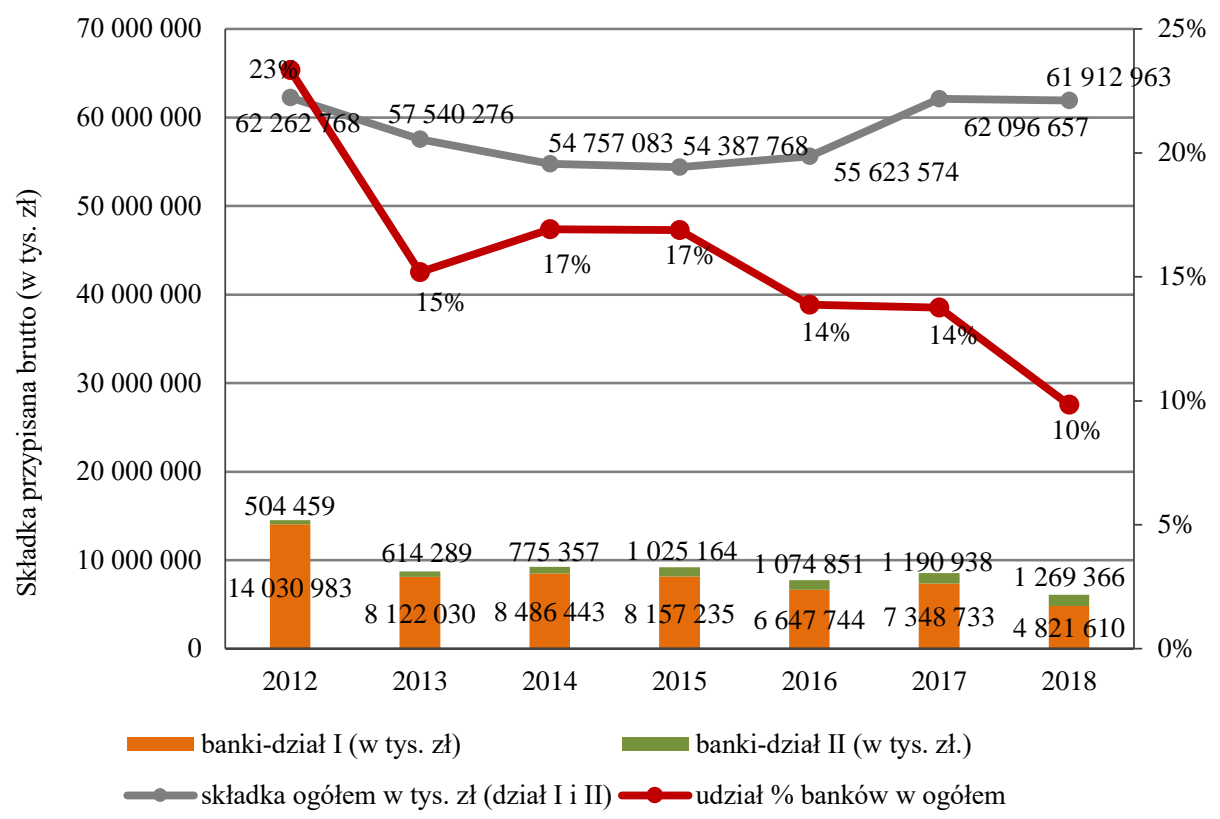

Wykres 1. Składka przypisana brutto wg działów w latach 2012-2018 w kanale bancassurance

Źródło: opracowanie własne na podstawie bazy danych KNF, 2012-2018, tablice: V.5, V.6, V.12.

Analizując udział banków (jako agentów ubezpieczeniowych) w sprzedaży produktów ubezpieczeniowych należy zauważyć trend spadkowy. W latach 20122018 udział ten zmniejszył się o 13 pp. Spadek w znacznej mierze dotyczył produktów działu I, bowiem ich udział w składce przypisanej brutto zmniejszył się o 9 mld zł (o 15\%). W dziale II, w analizowanym okresie nastąpił przyrost składki o 0,76 mld zł. Biorąc pod uwagę, że udział działu II jest niewielki w sprzedaży produktów ubezpieczeniowych przez banki (według składki przypisanej brutto) wzrost ten miał małe znaczenie dla ogólnej sytuacji na rynku bancassurance (wykres 1).

Poniżej przedstawiono analizę dla poszczególnych działów, która pokazuje znaczenie omawianego kanału dystrybucji w sprzedaży produktów życiowych (dział I) oraz majątkowych i innych osobowych (dział II). 


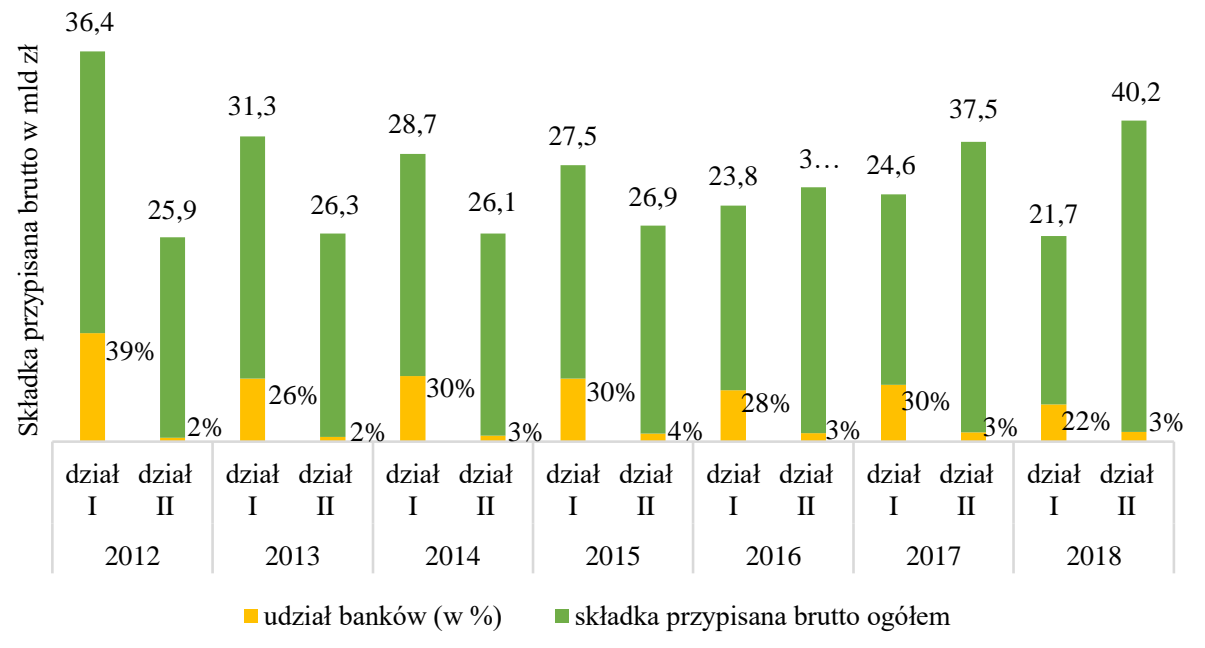

Wykres 2. Udział banków w składce przypisanej brutto w latach 2012-2018 wg działów

Źródło: opracowanie własne na podstawie bazy danych KNF, 2012-2018, tablice: V.5, V.6, V.12.

W roku 2012 za pośrednictwem banków sprzedawanych było prawie $40 \%$ produktów ubezpieczeniowych działu I co pozwoliło uzyskać ponad $14 \mathrm{mld}$ zł składki przypisanej brutto. W tym samym roku sprzedaż w dziale II była na poziomie niespełna $2 \%$ ogółu składki tego działu (tj. ok. 0,5 mld. zł). W kolejnych latach obserwowany był systematyczny spadek udziału sprzedaży produktów działu I przez banki do poziomu $22 \%$ w 2018 r. Największy spadek miał miejsce w 2013 r. o 13\% co miało związek z wejściem w życie 1 stycznia 2013 III rekomendacji dobrych praktyk na polskim rynku bancassurance, równocześnie zaktualizowana została I rekomendacja dobrych praktyk w zakresie ubezpieczeń ochronnych powiązanych z produktami bankowymi (szerzej w: Makowiecki, 2012: 11). Kolejny znaczny spadek miał miejsce w 2018 r. tj. po wejściu w życie nowej ustawy dotyczącej dystrybucji ubezpieczeń. W dziale II ubezpieczeń następował niewielki wzrost udziału sprzedaży produktów ubezpieczeniowych przez banki do poziomu 1,3 mld zł w $2018 \mathrm{r}$. (wykres 1, 2).

Sytuacja w zakresie sprzedaży produktów przez kanał bankowy była omawiana na XI Kongresie Bancassurance (w 2019 r.), podczas którego stwierdzono, że przyczyną trendu spadkowego było zmniejszenie przypisu składki z produktów inwestycyjnych (głównie ubezpieczeń na życie z funduszem kapitałowym), przy jednoczesnym wzroście wpływów z pozostałych rodzajów umów. Ponadto 
zmniejszała się popularność produktów grupowych na korzyść indywidualnych, wyjątek stanowiły tu umowy OC, w przypadku których rosło znaczenie umowy grupowej (Gocałek, 2019).

Systematyczne badania dotyczące rynku bancassurance w Polsce przeprowadza Polska Izba Ubezpieczeń (PIU). Raporty z tych badań powstają w oparciu o dane przesłane przez większość towarzystw ubezpieczeniowych (badaniem objętych było min. 97\% zakładów działu I i 84\% działu II biorąc pod uwagę ich udział w rynku danego działu wg składki przypisanej brutto).

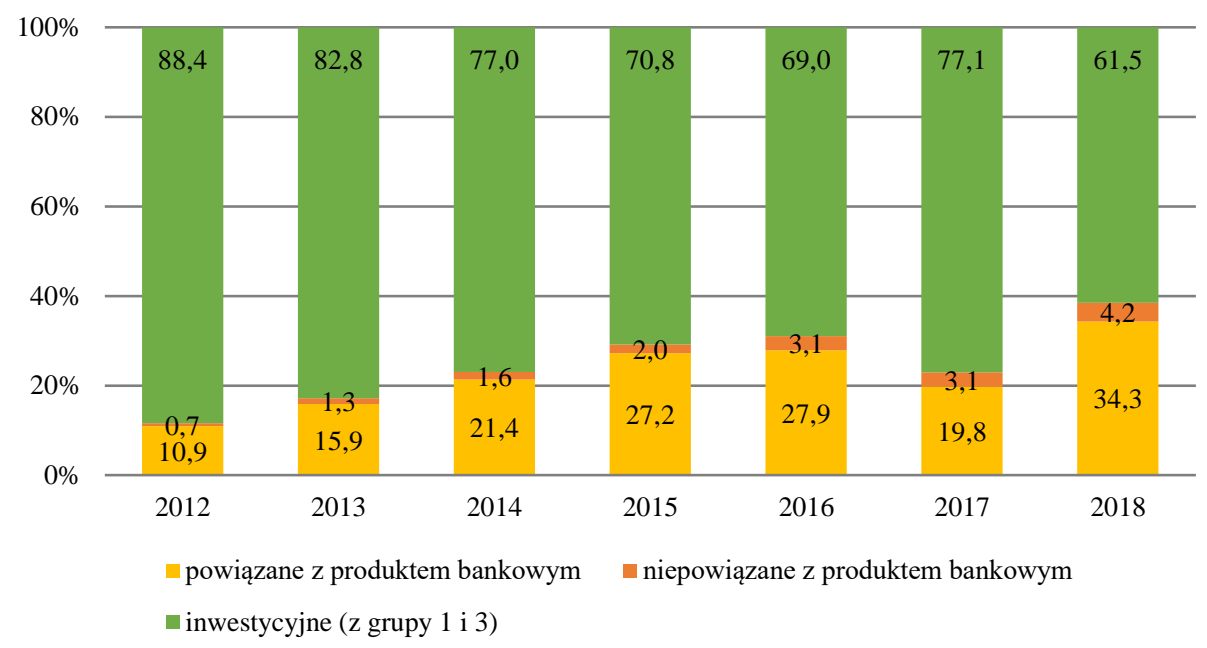

Wykres 3. Udział produktów działu I w składce przypisanej brutto pozyskanej w kanale bancassurance w latach 2012-2018

Źródło: opracowanie własne na podstawie bazy danych PIU, 2016: 8; PIU 2017: 8; PIU 2018: 10,11 .

W dziale I w kanale bancassurance największy udział w składce miały produkty inwestycyjne. Pomimo systematycznego spadku ich udziału (o 27 p.p. w 2018 r. względem 2012 r.) to jednak ich znaczenie biorąc pod uwagę składkę jest wysokie - ponad 60\% udziału w 2018 r. (wykres 3). Analizując liczbę zawartych umów ubezpieczeń, należy zauważyć, że największy udział mają produkty sprzedawane w powiązaniu z produktem bankowym (wykres 4). 


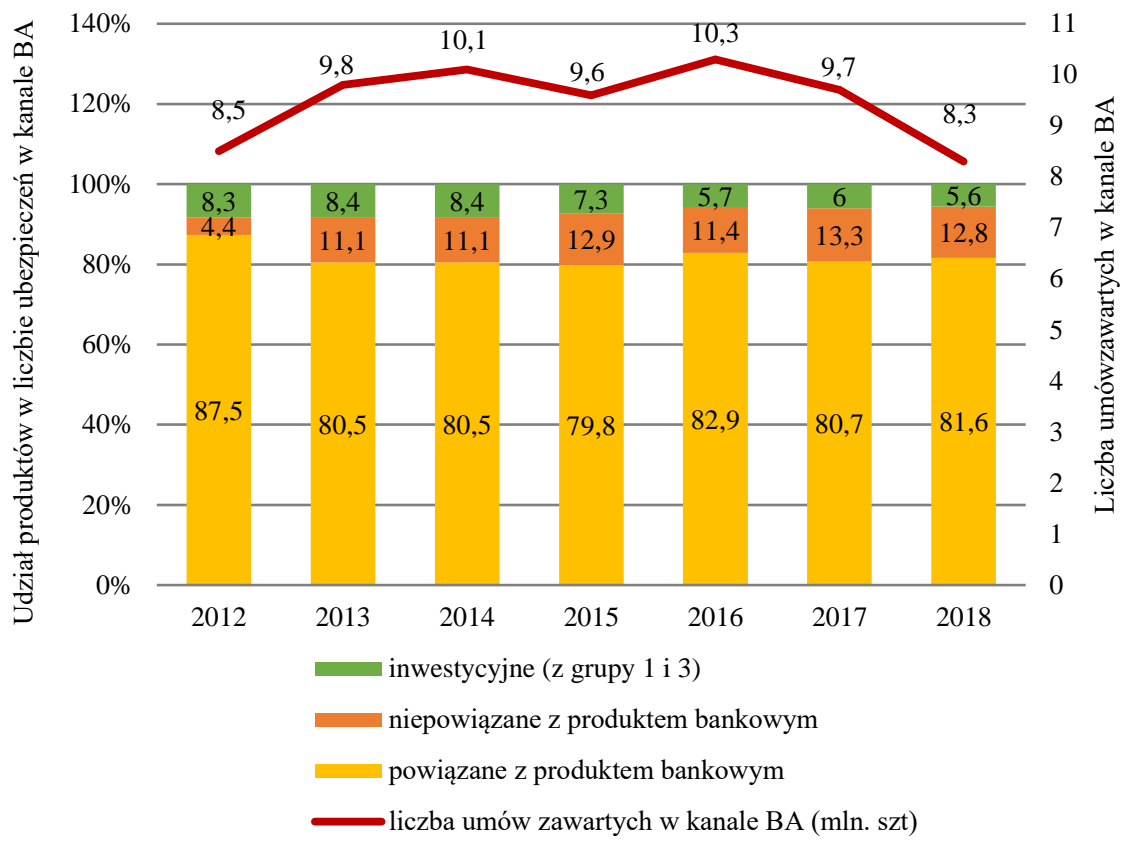

Wykres 4. Udział produktów działu I w liczbie ubezpieczeń w kanale bancassurance (BA) w latach 2012-2018

Źródło: opracowanie własne na podstawie bazy danych PIU, 2017: 8, 9; PIU 2018: 11, 12.

Porównując liczbę wszystkich umów zawartych w dziale I w kanale bancassurance na początku i końcu analizowanego okresu (2012 r. i 2018 r.) należy stwierdzić, że osiągnęły one podobny poziom. Pomiędzy tymi latami odnotowano niewielkie wzrosty i spadki. Najwyższa wartość sprzedanych polis została odnotowana w 2016 r. tj. 10,3 mln szt.

Ubezpieczenia sprzedawane razem z produktem bankowym stanowiły ponad $80 \%$ produktów dostarczanych w ramach bancassurance. W latach 2012-2018 zaobserwować można było spadek ich udziału (o 6 p.p.). Jednak biorąc pod uwagę wartość wg składki przypisanej brutto stanowiły one ok 1/3 przychodów w $2018 \mathrm{r}$. $\mathrm{i}$ był to najwyższy wynik $\mathrm{w}$ analizowanym okresie. $\mathrm{Z}$ kolei udział produktów inwestycyjnych w liczbie ubezpieczeń (tj. w liczbie aktywnych ubezpieczonych (PIU, 2018: 5) był niewielki (poniżej 10\%) i systematycznie malał od 2012 r. (z 8,3\% do 5,6\%) to jednak ich udział w składce był największy (wykres 4).

Wśród produktów inwestycyjnych zdecydowanie dominowały ubezpieczenia $\mathrm{z}$ grupy 3 (ubezpieczenia na życie, jeżeli są związane z ubezpieczeniowym funduszem kapitałowym, a także takie, w których świadczenie jest ustalane w oparciu 
o określone indeksy lub inne wartości bazowe), ich udział w składce przypisanej brutto zwiększył się z 86\% w 2015 r. do $96 \%$ w 2018 r. oraz produkty sprzedawane jako indywidualne ( $81 \%$ w 2015 r. i 88\% w 2018 r.). Natomiast wśród produktów ochronnych, powiązanych z produktem bankowym (dla zabezpieczenia spłaty kredytu) widoczna była wyraźna zmiana w sprzedaży produktów indywidualnych i grupowych. W 2014 r. zdecydowanie przeważały umowy grupowe (99\%), ale już od 2015 r. nastąpił znaczny spadek (do 35\%) i w kolejnych latach udział ten się zmniejszał na korzyść ubezpieczeń zawieranych indywidualnie, których udział w 2018 r. wyniósł 95\%. W przypadku pozostałych ubezpieczeń ochronnych również widoczna była podobna tendencja jednak udziały nie uległy aż tak dużym zmianom: w 2014 r. przeważały ubezpieczenia sprzedawane grupowo (ich udział wyniósł 85\%), w 2016 r. przeważały nieznacznie ubezpieczenia indywidualne (51\%), których udział w 2018 r. wyniósł 78\% (PIU, 2017: 14, 16; PIU, 2018: 13, 17, 19).

Poniżej przedstawiono analogiczną analizę dla działu II ubezpieczeń.

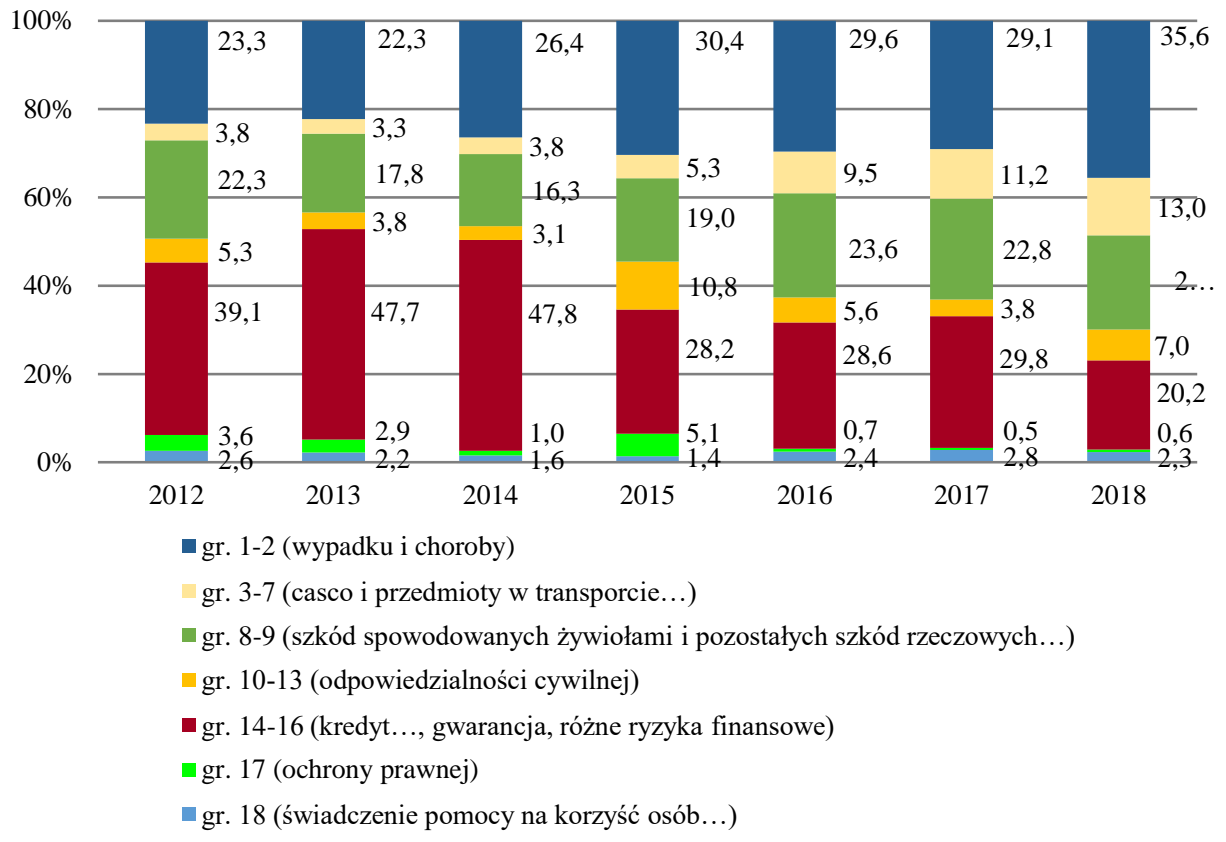

Wykres 5. Udział produktów działu II w składce przypisanej brutto pozyskanej w kanale bancassurance w latach 2012-2018

Źródło: opracowanie własne na podstawie bazy danych PIU, 2016: 23; PIU, 2017: 23; PIU, 2018: 28. 


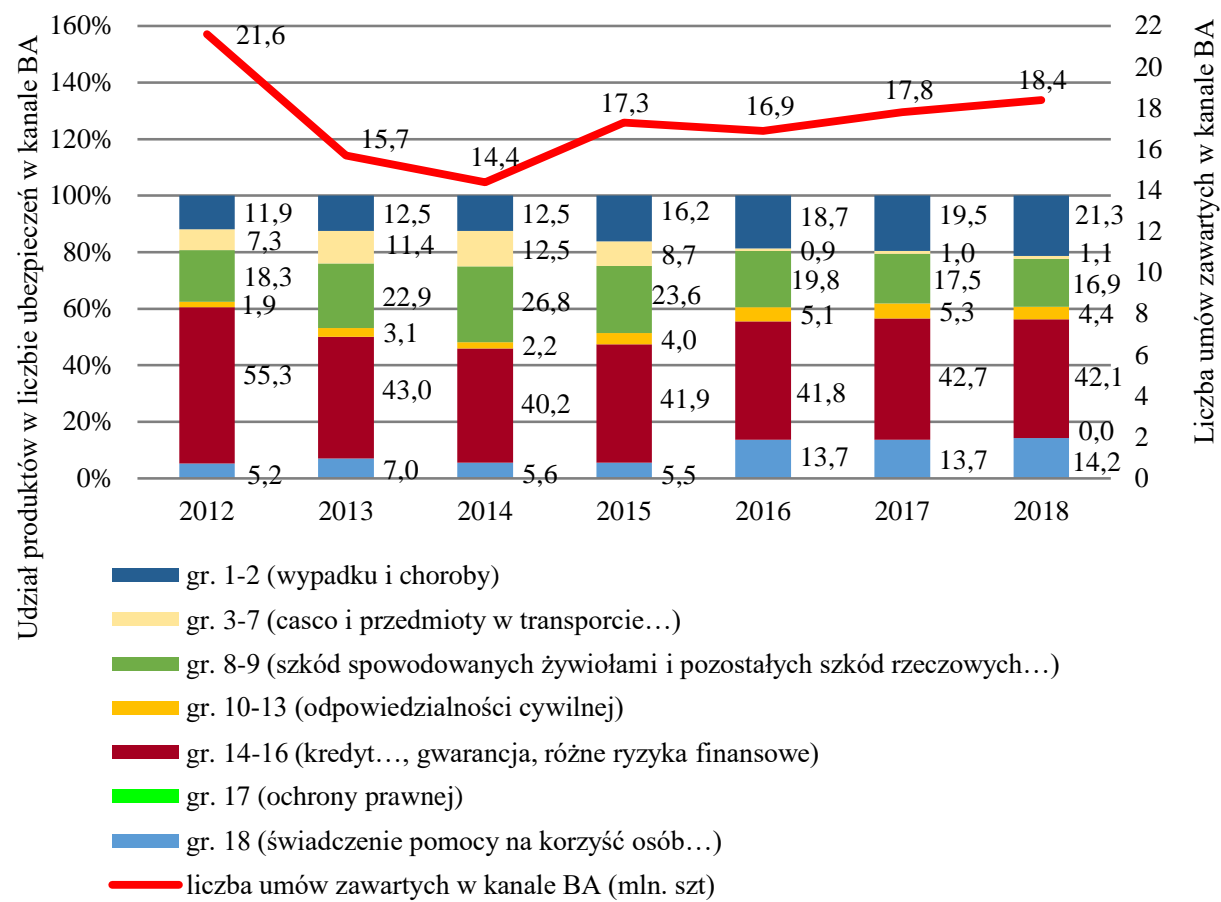

Wykres 6. Udział produktów działu II w liczbie ubezpieczeń w kanale bancassurance w latach 2012-2018

Źródło: opracowanie własne na podstawie bazy danych PIU, 2017: 25; PIU, 2018: 29.

Analizując powyższe wykresy należy stwierdzić, że coraz większą popularność w sprzedaży produktów ubezpieczeniowych przez bank zyskują ubezpieczenia osobowe działu II (wypadkowe i chorobowe). Biorąc pod uwagę składkę przypisaną brutto ich udział zwiększył się o ponad 12 p.p., a liczbowo o ponad 9 p.p. Dużym zainteresowaniem $\mathrm{w}$ ramach kanału bancassurance cieszą się również produkty z grup 8-9 (pozostałe ubezpieczenia spowodowane żywiołami i szkód rzeczowych). Ich udział w składce przypisanej brutto w analizowanym okresie utrzymywał się na poziomie ok 20\% (z wyjątkiem lat - 2013 i 2014, kiedy nastąpił niewielki spadek udziału). Natomiast udział tych produktów w liczbie ubezpieczeń systematycznie malał od 2014 r. (spadek o 10\%). Odwrotna sytuacja miała miejsce w przypadku produktów z grup 14-16 (ubezpieczenie kredytu, gwarancja ubezpieczeniowa, ubezpieczenia ryzyka finansowego). Ich udział w składce przypisanej brutto ulegał ciągłemu spadkowi od 2013 r. (z 48\% do 20\%), natomiast utrzymywała się wysoka liczba sprzedaży tych produktów (udział wynosi ponad 
$40 \%$ od 2013 r.). Należy także zaznaczyć, że systematycznie od 2012 r. wzrastała liczba sprzedaży poprzez banki produktów grupy 18 (ubezpieczenia świadczenia pomocy na korzyść osób, które popadły w trudności w czasie podróży lub podczas nieobecności w miejscu zamieszkania - głównie tzw. ubezpieczenia turystyczne). Udział tych produktów zwiększył się w 2018 r. prawie trzykrotnie w porównaniu do roku 2012. Jednak składka przypisana brutto z ich tytułu utrzymywała się na niewielkim poziomie (udział poniżej 3\%). $Z$ kolei udział umów zawartych w ramach grup 3-7 (casco i przedmiotów w transporcie) według składki przypisanej brutto charakteryzował trend wzrostowy (od 3,8\% w 2012 r. do $13 \%$ w 2018 r.), ale liczba zawartych umów malała (w 2014 r. udział wyniósł 12\% a w 2018 r. 1\%). Udział umów odpowiedzialności cywilnej (grupy 10-13) w liczbie sprzedanych produktów przez banki był na niskim poziomie (poniżej $5 \% \mathrm{w}$ analizowanym okresie). Największy udział tych ubezpieczeń w składce przypisanej brutto miał miejsce w 2015 r. (11\%), wysoki poziom odnotowano także w 2018 r. (7\%). Ubezpieczenia ochrony prawnej (grupa 17) stanowiły niewielki odsetek produktów sprzedawanych przez kanał bancassurance.

Ogólną liczbę zawartych umów w dziale II w okresie 2012-2014 w kanale bancassurance charakteryzował trend spadkowy (liczba umów w 2014 r. była mniejsza o 7,2 mln szt. tj o 33\% względem roku 2012). W kolejnych latach rosła liczba zawartych umów jednak nie uzyskała ona poziomu z 2012 r. Różnica pomiędzy 2018 r. a 2012 r. wyniosła 3,2 mln szt, (tj. o 15\% mniej w 2018 r.).

Analiza sprzedaży, uwzględniająca podział produktów ubezpieczeniowych na indywidualne i grupowe (w dziale II) wskazała, że malał udział (wg liczby) ubezpieczeń grupowych na korzyść produktów indywidualnych (z 91\% w 2015 r. do $65 \%$ w 2018 r.). Analogiczne zmiany miały miejsce przy uwzględnieniu składki przypisanej brutto. Udział produktów indywidualnych zwiększył się o ponad 30 p.p. w 2018 r. względem 2015 r. (kiedy wynosił 31\%). Jednak w 2018 r. odnotowano mniejszy udział $\mathrm{w}$ składce produktów indywidualnych względem roku 2017 (spadek z 70\% do 62\%). Największy i rosnący udział w składce miały produkty indywidualne sprzedawane w ramach grup 1-2 (osobowe) i 14-16 (w 2018 r. udział wyniósł odpowiednio: 38\% i 28\%). Biorąc pod uwagę liczbę ubezpieczeń udział tych grup w 2018 r. był na poziomie $31 \%$ dla grup $14-16$ i $28 \%$ dla grup 1-2. W ramach produktów grupowych największy spadek udziału w liczbie ubezpieczeń został odnotowany w grupach 3-7 (casco i przedmioty w transporcie) z 13\% w 2014 r. do $1 \%$ w 2018 r. (tj. spadek z 1757 tys. szt. do 138 tys. szt.). Natomiast przyrost jest widoczny w grupie 18, której udział zwiększył się z 5\% w 2014 r. do 15\% w 2018 r. (tj. wzrost z 734 tys. szt. do 1810 tys. szt.). W ramach ubezpieczeń grupowych na wysokim poziomie utrzymywała się sprzedaż produktów z grup 14-16 (ok. $6 \mathrm{mln}$ szt.), a ich udział wynosił ponad 40\% (w 2018 r. - 48\%) (obliczenia na podstawie PIU, 2018: 30-34). 
Porównując dział I i II należy zauważyć, że liczba sprzedanych polis w dziale II była znacznie wyższa w całym analizowanym okresie. Największe różnice odnotowano w 2012 r. i 2018 r. (odpowiednio o ok: 13 mln szt. i $10 \mathrm{mln}$ szt.), a najmniejszą w 2014 r. (4,3 mln. szt.). Pomimo, że liczba zawartych umów w dziale II była wyższa to jednak składka uzyskana $\mathrm{z}$ ich tytułu była niższa niż w dziale I.

$\mathrm{Z}$ punktu widzenia prezentowanej analizy istotna jest również liczba podmiotów - banków prowadzących sprzedaż produktów ubezpieczeniowych. Dane przedstawiono na wykresie 7.

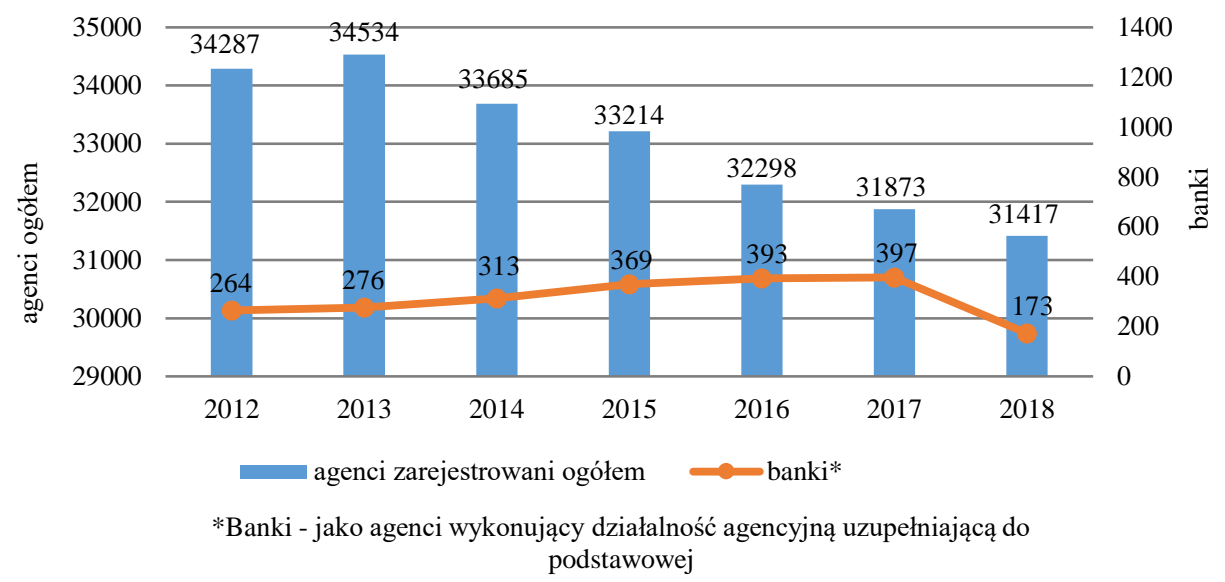

Wykres 7. Liczba zarejestrowanych agentów ubezpieczeniowych (w tym banków) w latach 2012-2018

Źródło: opracowanie własne na podstawie bazy danych KNF, 2013-2018, tablice: I.1.

Liczba agentów (wykonujących działalność agencyjną, jako uzupełniającą do podstawowej) będących bankami w latach 2012-2017 systematycznie rosła z 264 do 397 podmiotów, natomiast w 2018 zarejestrowanych było 173 podmiotów, co oznacza spadek liczby banków uczestniczących w bancassurance o 224 podmioty względem roku poprzedzającego. Udział agentów będących bankami w ogólnej liczbie agentów ubezpieczeniowych wyniósł w 2018 r. 0,6\%.

\section{ANALIZA OFERTY PRODUKTOWEJ BANCASSURANCE W 5 NAJWIĘKSZYCH BANKACH}

W IV kwartale 2018 r. w gronie 5 największych banków pod względem liczby klientów znalazły się: PKO BP S.A. (9,8 mln), Bank Pekao S.A. $(5,5 \mathrm{mln})$, Santander BP S.A. (4,9 mln), ING Bank Śląski S.A. (4,9 mln), mBank S.A. (4,4 mln) (Bankier.pl, 2019: 10). 
Banki, działające jako agent ubezpieczeniowy, posiadają pełnomocnictwa udzielone przez towarzystwa ubezpieczeniowe do wykonywania w imieniu i na rzecz danego zakładu ubezpieczeń czynności pośrednictwa ubezpieczeniowego. W pełnomocnictwie określone są działy i grupy ubezpieczeń oraz maksymalne sumy ubezpieczenia, dla których zostało udzielone pełnomocnictwo (przykładowe www 7,8). Wykaz banków i ubezpieczycieli na rzecz, których wykonują czynności ubezpieczeniowe wraz z grupami i przykładowymi ubezpieczeniami został przestawiony w tab. 2 .

Tabela 2. Współpraca między bankami a ubezpieczycielami w ramach bancassurance (na przykładzie 5 największych banków)

\begin{tabular}{|c|c|c|c|}
\hline \begin{tabular}{|} 
1. Nazwa banku/ \\
nr wpisu do rejestru \\
agentów ubezpiecze- \\
niowych w KNF/ \\
akcjonariat***
\end{tabular} & $\begin{array}{l}\text { 2. Nazwy TU, które udzieliły } \\
\text { pełnomocnictwa dla banku* }\end{array}$ & \begin{tabular}{|c|} 
3. Grupy ubez- \\
pieczeń, w ra- \\
mach których \\
prowadzona \\
jest sprzedaż**
\end{tabular} & 4. Przykładowe ubezpieczenia** \\
\hline 1 & 2 & 3 & 4 \\
\hline $\begin{array}{l}\text { PKO BP S.A. } \\
\text { 11160967/A }\end{array}$ & $\begin{array}{l}\text { Dział I: } \\
\text { • PKO Życie TU SA }\end{array}$ & $\begin{array}{l}\text { Dział I: } \\
1,5\end{array}$ & $\begin{array}{l}\text { - OC, AC, NNW, assistance komu- } \\
\text { nikacyjne } \\
\text { - turystyczne }\end{array}$ \\
\hline \begin{tabular}{|l|}
$3,8 \%$ Nationale-Ne- \\
derlanden OFE \\
$7,6 \%$ Aviva PLC \\
$31,4 \%$ Skarb Państwa \\
52,7\% pozostali
\end{tabular} & \begin{tabular}{|l} 
Dział II: \\
- AXA TUiR SA \\
- Cardif-Assurances Risques \\
Divers S.A. Odz. w Polsce \\
- Compensa TU SA Vienna \\
Insurance Group \\
- Generali TU SA \\
- INTERRISK TU SA Vienna \\
- Insurance Group \\
- KUKE SA \\
- PKO TU SA \\
- PZU SA \\
- STU ERGO Hestia SA \\
\end{tabular} & $\begin{array}{l}\text { Dział II: } \\
1-3 \\
7-10 \\
13-18\end{array}$ & $\begin{array}{l}\text { - mieszkania (nieruchomość, rucho- } \\
\text { mości, OC w życiu prywatnym, } \\
\text { assistance) } \\
\text { - na życie (samodzielne, dla posia- } \\
\text { daczy ROR, kredytów i pożyczek, } \\
\text { kart bankowych) } \\
\text { - zdrowotne } \\
\text { - na wypadek utraty źródła dochodu } \\
\text { lub poważnego zachorowania, po- } \\
\text { bytu w szpitalu w wyniku NW } \\
\text { (dla posiadaczy kredytów i poży- } \\
\text { czek) }\end{array}$ \\
\hline \begin{tabular}{l|} 
Bank Pekao SA \\
11145778/A \\
20\% PZU \\
12,8\% Polski Fundusz \\
Rozwoju \\
6,5\% UniCredit \\
5,8\% Aviva PLC \\
54,9\% pozostali
\end{tabular} & 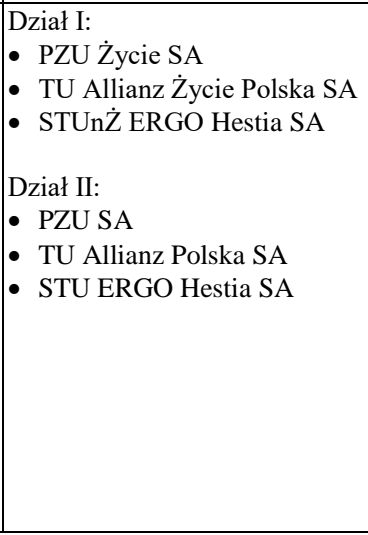 & \begin{tabular}{|l} 
Dział I: \\
1,5 \\
\\
Dział II: \\
$1-3$, \\
$8-10$, \\
13, \\
$16-18$
\end{tabular} & $\begin{array}{l}\text { - na życie (do pożyczki gotówko- } \\
\text { wej, dla spłacających kredyt } \\
\text { mieszkaniowy) } \\
\text { - hospitalizacja, niezdolność do } \\
\text { pracy, śmierć w wyniku NW (do } \\
\text { pożyczki gotówkowej, kredytu } \\
\text { mieszkaniowego) } \\
\text { - nieruchomości (mienie, ruchomo- } \\
\text { ści OC w życiu prywatnym) } \\
\text { - turystyczne (do kart kredytowych) } \\
\text { - na wypadek utraty zatrudnienia } \\
\text { (do pożyczki kredytowej lub kre- } \\
\text { dytu mieszkaniowego) } \\
\text { - PZU Dom } \\
\text { - PZU Wojażer (turystyczne) } \\
\text { - PZU Auto (komunikacyjne) }\end{array}$ \\
\hline
\end{tabular}




\begin{tabular}{|c|c|c|c|}
\hline 1. & 2. & 3. & 4. \\
\hline $\begin{array}{l}\text { Santander BP S.A. } \\
11135943 / A \\
66,3 \% \text { Banco Santan- } \\
\text { der } \\
5 \% \text { Nationale-Neder- } \\
\text { landen OFE } \\
28,7 \% \text { pozostali }\end{array}$ & $\begin{array}{l}\text { Dział I: } \\
\text { - Santander Aviva TUnŻ SA } \\
\text { - AXA Życie TU SA } \\
\text { - Generali Życie TU SA } \\
\text { - MetLife TUiR SA } \\
\text { - Open Life TUnŻ SA } \\
\text { - TUnŻ Europa SA } \\
\text { - TUnŻ Warta SA } \\
\text { - Vienna Life TUnŻ SA } \\
\text { Vienna Insurance Group } \\
\text { Dział II: } \\
\text { - Santander Aviva TU SA } \\
\text { - Aviva TU Ogólnych SA } \\
\text { - AXA Ubezpieczenia TUiR } \\
\text { - SA } \\
\text { - Compensa TU SA Vienna } \\
\text { - TU Eurance Group }\end{array}$ & $\begin{array}{l}\text { Dział I: } \\
1,5 \\
\text { Dział II: } \\
1-3, \\
7-10, \\
13, \\
16, \\
18\end{array}$ & $\begin{array}{l}\text { - na życie (samodzielne, do kredytu } \\
\text { gotówkowego lub w rachunku) } \\
\text { • chorobowe, pobyt w szpitalu NNW } \\
\text { (samodzielne na wypadek choroby } \\
\text { nowotworowej, do kredytu w ra- } \\
\text { chunku) } \\
\text { - na wypadek śmierci w wyniku NW } \\
\text { (samodzielne, do kredytu hipotecz- } \\
\text { nego, karty kredytowej) } \\
\text { - na wypadek niezdolności do pracy, } \\
\text { inwalidztwa w wyniku NW (do } \\
\text { kredytu hipotecznego lub w ra- } \\
\text { chunku kredytowym, karty kredy- } \\
\text { towej) } \\
\text { turystyczne (samodzielne, do karty } \\
\text { kredytowej) } \\
\text { - na wypadek utraty zatrudnienia (sa- } \\
\text { modzielne, do karty kredytowej, } \\
\text { kredytu gotówkowego) } \\
\text { - domu lub mieszkania (nieruchomo- } \\
\text { ści, ruchomości, assistance) } \\
\bullet \text { OC/AC komunikacyjne (dodat- } \\
\text { kowo assistance, NNW) } \\
\text { - na wypadek utraty karty, nieupraw- } \\
\text { nionego użycia karty (do kart debe- } \\
\text { towych lub kredytowych) } \\
\text { - do konta firmowego lub karty de- } \\
\text { betowej (np. nieuprawnione trans- } \\
\text { akcje, utrata gotówki /karty, OC, } \\
\text { NNW, pobyt w szpitalu, niezdol- } \\
\text { ność do pracy NNW) }\end{array}$ \\
\hline \begin{tabular}{|l|} 
ING Bank Śląski \\
S.A. \\
11171261/A \\
75\% ING Groep NV \\
7,8\% Aviva PLC \\
27,3\% pozostali
\end{tabular} & $\begin{array}{l}\text { Dział I: } \\
\text { - Aviva TUnŻ SA } \\
\text { - Nationale-Nederlanden } \\
\text { TUnŻ SA } \\
\text { - PZU Życie SA } \\
\text { - TUnŻ Europa SA } \\
\text { Dział II: } \\
\text { - Aviva TU Ogólnych SA } \\
\text { - NationaleNederlanden } \\
\text { TU SA } \\
\text { - PZU SA } \\
\text { - TU Europa SA }\end{array}$ & $\begin{array}{l}\text { Dział I: } \\
1,3,5 \\
\text { Dział II: } \\
1-3, \\
7-10 \\
13, \\
16-18\end{array}$ & $\begin{array}{l}\text { •na życie } \\
\bullet \text { NNW dla dziecka } \\
\bullet \text { na wypadek nowotworu i innych } \\
\text { poważnych chorób } \\
\text { •turystyczne } \\
\bullet \text { OC, AC, assistance komunikacyjne } \\
\bullet \text { na wypadek kradzieży lub utraty } \\
\text { gotówki (do karty do konta) } \\
\bullet \text { OC w życiu prywatnym (do karty } \\
\text { do konta) } \\
\bullet \text { dom i mieszkania (mienie, rucho- } \\
\text { mości, OC, assistance) } \\
\bullet \text { na wypadek utraty pracy, choroby } \\
\text { lub śmierci (do produktów hipo- } \\
\text { tecznych i pożyczek) } \\
\bullet \text { na życie z ubezpieczeniowym fun- } \\
\text { duszem kapitałowym } \\
\bullet \text { do konta firmowego i karty (np. } \\
\text { mienie, OC, śmierć w wyniku } \\
\text { NNW, nieuprawnione użycie karty) }\end{array}$ \\
\hline
\end{tabular}




\begin{tabular}{|c|c|c|c|}
\hline 1. & 2. & 3. & 4. \\
\hline \begin{tabular}{|l} 
mBank S.A. \\
11124813/A \\
69,3\% Commerzbank \\
AG \\
7,8\% Nationale-Ne- \\
derlanden OFE
\end{tabular} & $\begin{array}{l}\text { Dział I: } \\
\text { - AXA Życie TU SA } \\
\text { - Baloise Vie Luxembourg SA } \\
\text { - Compensa TUnŻ SA } \\
\text { Dział II: } \\
\text { - AXA Ubezpieczenia TUiR } \\
\text { SA }\end{array}$ & $\begin{array}{l}\text { Dział I: } \\
1 \\
\text { Dział II: } \\
1-3, \\
8-10, \\
13, \\
16, \\
18\end{array}$ & $\begin{array}{l}\text { - OC, AC, Assistance komunka- } \\
\text { cyjne } \\
\text { - domu/mieszkania } \\
\text { - turystyczne } \\
\text { - życie i zdrowie (na życie, NNW, } \\
\text { NNW dla dziecka, na wypadek no- } \\
\text { wotworu) } \\
\text { - pomoc finansowa (na wypadek } \\
\text { utraty pracy, poważnego zachoro- } \\
\text { wania, pobytu w szpitalu, śmierci) } \\
\text { - assistance (do karty debetowej) } \\
\text { - do kredytów firmowych (na życie, } \\
\text { utrata pracy, pobyt w szpitalu, } \\
\text { śmierć) }\end{array}$ \\
\hline
\end{tabular}

* Na podstawie danych z rejestru pośredników ubezpieczeniowych, stan z dnia 10.02.2020.

** Na podstawie informacji ze stron internetowych banków (karta produktu lub owu, luty 2020).

*** Na podstawie UKNF 2019: 29, 31, 35, 37, 39

Banki działające, jako agenci ubezpieczeniowi oferują produkty zarówno z działu I jak i II ubezpieczeń. Głównie są to produkty powiązane z bankowymi, ale również sprzedawane są produkty ubezpieczeniowe, jako samodzielne. W ramach działu I największe banki sprzedają produkty z grup 1 i $5 \mathrm{tj}$. ubezpieczenia na życie i tzw. ubezpieczenia dodatkowe. W czterech z pięciu analizowanych banków, pomimo posiadania przez nie pełnomocnictw do sprzedaży produktów grupy 3 (z ubezpieczeniowym funduszem kapitałowym), w momencie analizy nie oferowały one tego typu produktów. Analiza stanu wcześniejszego pokazuje, że takie produkty były w ofercie tych banków przed 2017 r. (www2). Jedynie ING Bank Śląski, w momencie analizy, posiadał w ofercie ubezpieczenie związane z UFK. W ramach działu II wszystkie banki prowadziły sprzedaż produktów grup: $1-3,8-10,13,16$ oraz 18 , trzy banki - w ramach grupy 7 i 17 , jeden bank - grupy $14 \mathrm{i} 15$. W ofercie żadnego banku nie pojawiły się produkty z grup: 4, 5, 6, 11 i 12 czyli ubezpieczenia casco i OC dotyczące pojazdów innych niż lądowe. Najszerszy zakres ubezpieczeń biorąc pod uwagę ilość grup oferował bank PKO BP, ale najbardziej zróżnicowana oferta produktowa była w banku Santander, co mogło wynikać z największej liczby pełnomocnictw otrzymanych przez ten bank (od 13 towarzystw). Dużą liczbę tego typu porozumień posiadał również bank PKO BP (11), w przypadku pozostałych banków ilość ta mieściła się w zakresie od 4 do 8. Analizując sprzedaż produktów ubezpieczeniowych konkretnego ubezpieczyciela przez banki należy zauważyć powiązania finansowe istniejące pomiędzy bankami a ubezpieczycielami. Głównym akcjonariuszem TU PKO i PKO Życie jest PKO BP stąd znaczna ilość produktów tych towarzystw znalazła się w ofercie 
dostępnej przez bank (KNF 2018: tab.II.13, tab.II.26), z kolei PZU jest głównym udziałowcem w Banku Pekao SA, co również znajduje odzwierciedlenie w przygotowanej ofercie dla klientów tego banku, podobnie w przypadku banku Santander - udział Santander Aviva TU i TUnŻ (w których Santander Bank ma 49\% udziały).

\section{WNIOSKI}

Bancassurance z pewnością jest ważnym dla produktów ubezpieczeniowych kanałem dystrybucji, o dużym potencjale rozwoju, daje bowiem możliwość dotarcia do szerokiej grupy odbiorców. Rozbudowana sieć banków, liczba ich klientów i sprzedawanych produktów, które mogą być oferowane wraz z ubezpieczeniami są ważnym polem pozyskiwania nowych klientów przez ubezpieczycieli. Jednak sprzedaż produktów ubezpieczeniowych poprzez ten kanał wykazuje tendencją spadkową. W 2012 r. odnotowany został znaczny udział bancassurance w sprzedaży produktów ubezpieczeniowych osiągając prawie 1/4 składki przypisanej brutto ogółem. W kolejnych latach, wprowadzone nowe regulacje prawne (w tym rekomendacje) spowodowały zmniejszenie tego udziału (do 10\% w 2018 r.). Biorąc pod uwagę przychody ze sprzedaży produktów ubezpieczeniowych przez kanały bankowe w analizowanym okresie dominowały ubezpieczenia życiowe, natomiast niewielki był udział produktów działu II. Jednak liczbowo zdecydowanie przeważały umowy obejmujące produkty działu II, co wynika z dużej rozbieżności w wysokości składek na ubezpieczenia w poszczególnych działach. W dziale I pod względem składki przypisanej brutto dominowały produkty inwestycyjne i wykazywały tendencję malejącą, natomiast najczęściej sprzedawane były ubezpieczenia powiązane z produktem bankowym. W dziale II z kolei widoczny był wzrost znaczenia produktów chorobowych i wypadkowych (wg składki przypisanej brutto), ilościowo dominowały produkty związane z ryzykami finansowymi. Liczba banków, które działały jako agenci ubezpieczeniowy stanowiła niewielki odsetek wszystkich agentów, jednak należy podkreślić, że wśród agentów ubezpieczeniowych dominują osoby fizyczne. W 2018 r. nastąpił wyraźny spadek udziału banków, co w dużej mierze wynikało z nowych uregulowań wprowadzonych ustawą o dystrybucji ubezpieczeń.

W sprzedaży produktów ubezpieczeniowych zdecydowanie dominują kanały pośrednie, szczególnie istotne znaczenie ma sprzedaż poprzez agentów ubezpieczeniowych, stąd każde zewnętrzne źródło pozyskiwania klientów jest bardzo ważne dla zakładów ubezpieczeń, zwłaszcza przy współpracy z dużymi partnerami jakimi są banki.

Niesprzyjające i niepewne uwarunkowania na rynku bankowym (m.in. związane z orzeczeniami TSUE odnośnie walutowych kredytów hipotecznych) mogą 
stanowić szansę dla rozwoju bancassurance, gdyż banki będą zainteresowane wprowadzaniem lub rozszerzaniem współpracy w tym zakresie. Nową szansą może być idea open banking, która dzięki dyrektywie PSD2 (Dyrektywa Parlamentu Europejskiego i Rady (UE) 2015/2366) uzyskała nowy wymiar - ubezpieczyciele uzyskają lepszy dostęp do danych bankowych (www1).

\section{LITERATURA I MATERIAŁY ŹRÓD ŁOWE}

Bankier.pl, 2019, Raport Polska bankowość w liczbach IV kwartał 2018, https://prnews.pl/wp-content/uploads/2019/04/polska_bankowosc_w_liczbach_iv_kw_2018.pdf [dostęp: 8.03.2020].

Borowiec, L. (2011). Zintegrowany model bancassurance na polskim rynku finansowym. Prace $\mathrm{Na}$ ukowe Uniwersytetu Ekonomicznego we Wrocławiu, nr 158.

Czubała, A. (1997). Dystrybucja. W: J. Altkorn, red., Podstawy marketingu, Kraków: Wydawnictwo Instytut Marketingu.

Dołhasz, M., Fudaliński, J., Kosała, M., Smutek, H. (2009). Podstawy zarzadzania. Koncepcje strategie - zastosowania. Warszawa: Wydawnictwo PWN.

Dominiak M. (2018). Organizacja działalności prywatnych zakładów ubezpieczeń. W: M. IwaniczDrozdowska, red., Ubezpieczenia, Warszawa: Wydawnictwo PWE.

Dyrektywa Parlamentu Europejskiego i Rady (UE) 2015/2366 z dnia 25 listopada 2015 r. w sprawie usług płatniczych w ramach rynku wewnętrznego.

Dyrektywę Parlamentu Europejskiego i Rady (UE) 2016/97 z dnia 20 stycznia 2016 r. w sprawie dystrybucji ubezpieczeń.

Filkiewicz S. (2009). Zarządzanie relacjami z klientem na bazie wiedzy. W: J. Komorowski, J. Moczydłowska, red., Innowacyjne metody i techniki zarządzania w przedsiębiorstwie. Białystok: Wydawnictwo Wyższej Szkoły Finansów i Zarządzania w Białymstoku.

Gocałek, A. (2019). Przewodnicząca Zespołu ds. Bancassurance i Sprzedaży Affinity PIU, 17.10.2019, XI Kongres Bancassurance, ZBP, www.zbp.pl/aktualnosci/wydarzenia/XI-Kongres-Bancassurance [dostęp 16.01.2020].

KNF, 2012-2018, Biuletyn roczny. Rynek ubezpieczeń. Sprawozdanie statystyczne.

KNF, 2013-2018, Biuletyn roczny. Rynek ubezpieczeń. Informacje o pośrednikach.

KNF, 2014, Rekomendacja U dotycząca dobrych praktyk w zakresie bancassurance.

KNF, 2016a, Rekomendacje dla zakładów ubezpieczeń dotyczące badania adekwatności produktu.

KNF, 2016b, Rekomendacje dla zakładów ubezpieczeń dotyczące systemu zarządzania produktem.

KNF, 2018, Biuletyn roczny. Rynek ubezpieczeń. Informacje o krajowych zakładach ubezpieczeń.

Lisowski, J., Zieniewicz, M. (2015). Zmiany w kanale agencyjnym na rynku ubezpieczeniowym w Polsce. Annales Universitatis Mariae Curie-Skłodowska, Lublin, DOI:10.17951/h.2015. 49.4.335.

Makowiecki, A. (2012). III rekomendacja dobrych praktyk. Gazeta ubezpieczeniowa, 46.

Malinowska, K. (2017). Pojęcie zarządzania produktem ubezpieczeniowym w świetle dyrektywy o dystrybucji ubezpieczeń i przepisów implementacyjnych. Wiadomości Ubezpieczeniowe, 1.

Maśniak, D. (2015). Ramy prawne bancassurance. Gdańskie Studia Prawnicze, t. XXXIII.

Orłowski, C. (2015). Bancassurance z punktu widzenia Rzecznika Ubezpieczonych. Monitor Ubezpieczeniowy, 62.

PIU, 2016, Polski Rynek Bancassurance.

PIU, 2017, Polski Rynek Bancassurance.

PIU, 2018, Polski Rynek Bancassurance.

Rodek, K., Visan, J. (1997). Marketing ubezpieczeń na życie, Warszawa: Poltext. 
Stęplewska, K. (2015). Pośrednik ubezpieczeniowy a wizerunek towarzystwa ubezpieczeń na życie. Ekonomika i Organizacja Przedsiębiorstwa, 1.

UKNF, 2019, Przegląd sytuacji finansowej i rynkowej banków notowanych na GPW oraz inwestorów strategicznych w latach 2014-2018 na podstawie danych Bloomberg.

Ustawa z dnia 11 września 2015 r. o działalności ubezpieczeniowej i reasekuracyjnej, Dz.U. 2015 poz. 1844 ze zm.

Ustawa z dnia 15 grudnia 2017 r. o dystrybucji ubezpieczeń, Dz.U. 2017 poz. 2486 ze zm.

Ustawa z dnia 29 sierpnia 1997 r. Prawo bankowe, Dz.U. 1997 Nr 140 poz. 939 ze zm.

Witkowska, J. (2008). Kanały dystrybucji ustug ubezpieczeniowych. Toruń: Wydawnictwo „Dom Organizatora".

Witkowska, J. (2016). Kanały dystrybucji ubezpieczeń. W: D. Ostrowska, P. Jamrózm, red., Ubezpieczenia gospodarcze i społeczne w Polsce, Warszawa: Wydawnictwo CeDeWu.Pl.

ZBP, 2009, Rekomendacja (I) dobrych praktyk na polskim rynku bancassurance w zakresie ubezpieczeń ochronnych powiązanych z produktami bankowymi.

ZBP, PIU, 2010, Rekomendacja (II) w sprawie dobrych praktyk w zakresie ubezpieczeń finansowych powiązanych z produktami bankowymi zabezpieczonymi hipotecznie.

ZBP, PIU, 2012, Rekomendacja (III) dobrych praktyk na polskim rynku bancassurance w zakresie ubezpieczeń z elementem inwestycyjnym lub oszczędnościowym.

[www1] www.zbp.pl/aktualnosci/wydarzenia/XI-Kongres-Bancassurance [dostęp: 16.01.2020]

XI Kongres Bancassurance.

[www2] www.pkobp.pl/klienci-indywidualni/ubezpieczenia/ubezpieczenia-wycofane-z-oferty/polisa-dlugoterminowego-inwestowania/ [dostęp: 19.02.2020], Polisa długoterminowego inwestowania przygotowana przez PKO Życie dla klientów PKO BP.

[www3] file:///C:/Users/Start/Downloads/20190405-informacja-agenta-ubezpieczeniowegoidd.pdf [dostęp: 17.01.2020].

[www4] www.aliorbank.pl/dodatkowe-informacje/przydatne-dokumenty/dokumenty-prawne.html [dostęp: 17.01.2020].

[www5] file:///C:/Users/Start/Downloads/pelnomocnictwo-metlife.pdf [dostęp: 17.01.2020].

[www6] file:///C:/Users/Start/Downloads/informacja-agenta-ubezpieczeniowego-bez-ryczaltu.pdf [dostęp: 17.01.2020].

[www7] www.pkobp.pl/media_files/03797394-1f15-4f4b-8a4c-08dbee4068ac.pdf [dostęp: 17.02.2020].

[www8] www.ing.pl/_fileserver/item/1119939 [dostęp: 17.02.2020].

\section{ZNACZENIE BANCASSURANCE W PROCESIE ZARZĄDZANIA SPRZEDAŻĄ PRODUKTÓW UBEZPIECZENIOWYCH (ANALIZA DANYCH STATYSTYCZNYCH ZA LATA 2012-2018)}

\section{Streszczenie}

Celem artykułu jest prezentacja i ocena sytuacji w zakresie bancassurance w Polsce oraz ustalenie znaczenia tego kanału w sprzedaży produktów ubezpieczeniowych. Artykuł koncentruje się na problematyce dystrybucji produktów, która stanowi bardzo ważną część działalności każdego przedsiębiorstwa. Jednym z kanałów dystrybucji produktów ubezpieczeniowych jest bancassurance, bazujący na współpracy pomiędzy bankami a ubezpieczycielami.

Metodyka. Dla realizacji celu dokonano analizy zmian ilościowych, a także przeglądu wprowadzonych rozwiązań prawnych w odniesieniu do bancassurance. $W$ artykule zaprezentowano dane dotyczące rynku bancassurance w Polsce, z uwzględnieniem liczby i struktury sprzedaży w tym kanale w latach 2012-2018. 
Wyniki badania. Przeprowadzona analiza pozwoliła stwierdzić, że bancassurance jest ważnym kanałem dystrybucji produktów ubezpieczeniowych, o dużym potencjale rozwoju. Jednak w analizowanym okresie, sprzedaż przez ten kanał wykazywała tendencję spadkową co w głównej mierze spowodowane było wprowadzeniem nowych rekomendacji i regulacji prawnych dotyczących dystrybucji produktów ubezpieczeniowych.

Słowa kluczowe: przedsiębiorstwo ubezpieczeniowe, produkty ubezpieczeniowe, kanały dystrybucji, bancassurance, banki. 